Golec, M. M. (2017). Locality and the transfer of funds in the cooperative banking sector in Poland. Copernican Journal of Finance \& Accounting, 6(3), 21-33. http://dx.doi.org/10.12775/ CJFA.2017.014

\author{
Maria Magdalena Golec* \\ WSB University in Poznan
}

\title{
LOCALITY AND THE TRANSFER OF FUNDS IN THE COOPERATIVE BANKING SECTOR IN POLAND
}

Keywords: locality, net lenders, cooperative banks.

J E L Classification: G21, M21.

Abstract: One of the most important features of cooperative banks is locality which means concentrating financial activity on a specific area. The consequence of locating the banking activity locally is the use of funds raised from the local market for credit needs of the community. The barrier in this area may be an imbalance between the loans and deposits when the co-operative principle (the local money for local needs) is not met.

The paper aims to examine the scope of the principle of locality by the cooperative banks in Poland. The study uses quarterly financial data from the years 2009-2016 the selected group of 75 cooperative banks in Poland. The differentiation of the group of banks is assessed by means of descriptive statistics measurement tools and also in research it is used the econometric regression model.

Most cooperative banks are net lenders for money market in Poland. The average value of the loans to deposits ratio is 0.7 , and the scope of imbalance deepens in recent years. The reasons for such a situation are the regulations of the cooperative banking sector but also the individual policies of the institutions.

Date of submission: September 1, 2017; date of acceptance: November 7, 2017.

* Contact information: maria.golec@wsb.poznan.pl, WSB University in Poznan, ul. Powstańców Wielkopolskich 5, 61-895 Poznań, Poland, phone: 6565533 21; ORCID ID: https://orcid.org/0000-0003-2474-3987. 


\section{INTRODUCTION}

The attribute of cooperative banks that is most frequently brought out in scientific works, book titles, bank documents or banking sector reports is locality. Close relationship of credit unions with local communities may be a condition for credit cooperatives' survival and development (Siudek, 2011, p. 277).

A certain phenomenon is of local character only if it exists in a specific area/place (Latin: lokalis, lokus - place/location). As early as the 19th century credits cooperatives' membership was formally limited to those among whom there were mutual relationships - common bonds. In case there are not any social bonds among the members of a territorially limited area, the criterion that is often established for defining local communities is territory. Locality understood in this way becomes the basis for introducing formal limitations for credit cooperatives' activities (territory principle) (Szambelańczyk, 2006, p. 108). Barriers to the banks' development in the area of banking activities are treated as a kind of prudential norm. It is so because knowing the clients, their economic standing and limitations of the local environment decreases the credit risk, and, most of all, makes it possible to assess an actual economic standing of a prospective client. According to the Polish legal regulations the territory where a cooperative bank can perform its activities is dependent on the volume of its own funds. If the bank owns funds equal to or greater than EUR $5 \mathrm{~m}$ it can provide banking services all over the country. An affiliated cooperative bank with own funds greater than EUR 1m (but less than EUR 5m) may operate in the province (Polish: województwo) where its headquarters are based. In case the bank has lower own funds, it can operate in the district (Polish: powiat). The cooperative banks' charters mention several districts rather than one for their operations (Zalcewicz, 2010, pp. 181-182). In Poland 75\% of cooperative banks have own funds large enough to be able to operate in the province, $1 / 5$ of the cooperative banks can operate all over the country (Kozłowski, 2016, pp. 72-73). In practice, however, the banks themselves restrict the territory of their operations, as many as $42 \%$ of them have their branches only on the territory of one district (13\% in one commune [Polish: gmina] only) (Kozłowski, 2016, pp. 72-74).

The international cooperative principles adopted in 1995 and found in the Statement on the Co-operative Identity obligate the cooperative banks to, among others, "care about local community". Principle 7, being a novelty in comparison to the previous codifications, stipulates that cooperatives work for the sustainable development of their communities. It is worth mentioning that 
locality can be interpreted in wider terms as the realization of essential needs of specific communities by means of the banks' financial instruments, e.g. providing service for less affluent clients or financing investments important for specific communities (Alińska, 2008, p. 248; Giagnocavo \& Gerez, 2012, p. 284; Kata, 2011, p. 128; Golec, 2010, p. 72; Gostomski, 2010, p. 246).

Cooperative banks being legal entities whose purpose is to meet their members' and clients' financial needs perform these tasks by primarily providing access to financial resources in the form of loans. The positive impact of credit cooperatives activities on the economic growth of a local community occurs when the bank increases the scope of availability of the financial resources in the region. However, long-term exports of funds raised in the form of deposits, especially if the bank plays the role of the only financial institution in the region, may lead to its economic downgrading (Szambelańczyk \& Ławrynowicz, 2003, p. 393). From the point of view of a single institution, the more needs the cooperative bank will satisfy, the greater the degree to which it will realize the principle of locality (Kozłowski, 2016, p. 68; Rzerzycka \& GolanowskaWitkowska, 2015, p. 105). Although many market institutions may support initiatives important for local communities (e.g. by financing different kinds of needs), it is the cooperatives that can combine the social dimension and the economic dimension. The cooperatives banks through activities in the economic area (lending activities) may satisfy the local community's needs.

That is why the subject matter of this paper is the amounts of deposits raised by the cooperative banks and provided in the form of loans on the local market. Their offsetting or the prevalence of lending activities will signal the principle of locality at an appropriate level.

The aim of this paper is to examine the scope of the principle of locality by the cooperative banks in Poland, and to diagnose the causes of net transfers in the sector. The author used quarterly financial data for the years 2009-2016 encompassing a selected group of over 75 cooperative banks in Poland.

\section{TRANSFERS OF FUNDS IN THE COOPERATIVE BANKING SECTOR IN LITERATURE AND RESEARCH}

Cooperative banks like any other lending institutions are financial intermediaries that raise monetary funds from surplus spending units and satisfy the financial needs of deficit spending units (Boscia \& Di Salvio, 2009, p. 16; Becchetti, Ciciretti \& Paolantonio, 2016, p. 226). For the cooperative banks the de- 
posits are a basic method of financing loan activities because the availability of other sources of financing their activities is limited (Fonteyne, 2007, p. 11). The significance of deposit base results from the fact that there is no possibility for the cooperative banks to use directly monetary funds from the interbank market. Affiliating banks make a secondary source of financing these institutions. Affiliation with the cooperative structures and limited connections of the cooperative banks with the wholesale money market play also an essential role for these institutions' investment policies. For example, the cooperative banks in Poland having free funds are obliged by association agreements to deposit them in affiliating banks. On the other hand the intercooperative deposit market or deposits in commercial banks are of lesser importance (Czopur, 2012, p. 162).

The functioning of cooperative banks in a specific setting and regulatory limitations of the territorial activities cause traditional cooperative bank financial brokerage to be important for a specific community. This makes it possible for funds to flow within a specific area of activity. Unlike international commercial banks that make spatial transformations of the raised funds (Golec, 2016, p. 18), the cooperative banks can follow the historical cooperative principle "local money for local needs", thus offsetting deposit streams and loan volume (Szambelańczyk \& Ławrynowicz, 2003, p. 393; Szambelańczyk, 2006, pp. 111-113). If, however, the cooperative bank does not offset the streams of funds, then we deal with its: surplus (when the volume of customers' funds collected as deposits exceeds the value of amounts receivable of nonfinancial entities) or deficit (if the difference between deposits and loans is negative, the bank must borrow funds from other institutions, the institution is an "importer" of money capitals). In case of surplus of the cooperative bank, the "exports" of deposits lie in making deposits at an affiliating bank and through the affiliating bank in the wholesale money market. The optimal situation occurs when the cooperative bank offsets the streams of deposits and loans by only correcting surplus/deficit that result from temporary states. Among cooperative banks there may appear institutions that are "typically loan-oriented" or "typically deposit-oriented" (Siudek, 2011, p. 171).

The scope of money transfers among Polish cooperative banks was researched by Szambelańczyk and Ławrynowicz (2003). With the use of full quarterly financial data from 5 periods in the years 2000-2001 and with the use of two indicators, they established the differences between the values of clients' deposits and loans. They also identified relationships between the di- 
rection and scope of transfers and the profile of a bank's activity. Nearly half of the cooperative banks (49\%) demonstrated a balanced account of transfers, $13 \%$ of them were diagnosed as deficit-like, and the remaining were of surplus character (Szambelańczyk \& Ławrynowicz, 2003, pp. 400-402). The most deficit-like banks were based in small towns or villages. The surplus spending institutions were based in big agglomerations or close to them. In terms of the profile of activity the more surplus-like institutions were those of business character dealing mostly with businesses that provided lending services for farmers and households (Szambelańczyk, 2006, pp. 118).

The European cooperative banking sector's data do not corroborate the phenomena observed in Poland. According to the European Association of Cooperative Banks (EACB) representing 27 groups of cooperative banks with almost 80 million of members, 210 million of clients and 4050 cooperative banks, the 2015 loan-deposit ratio stood at 1.12, in the previous year's being pretty similar (Groeneveld, 2017, p. 5).

\section{ASSUMPTIONS OF THE RESEARCH}

The above-mentioned overview of the transfers of funds in the cooperative banking sector will be subjected to analysis with regard to the diversity of credit unions. The picture of the cooperative banking sector presented through value reports may be determined by merely a few very big market entities. That is why the author conducted a study of the scope of cooperative institutions' transfers with the use of financial data from 75 cooperative banks in Poland. The data used for the study encompassed the quarterly data for the period from December 2009 to March 2016. The data were provided by the Audit Association of Cooperative Banks in Poznań, one of the three audit associations of cooperative banks in Poland.

The differentiation of groups of banks will be assessed by means of descriptive statistics measurement tools. The categories taken into consideration are as follows: sum of assets, employment, sum of deposits, capitals, capital adequacy ratio, ROA.

For the diagnostic purpose of the scope of transfers in the researched group of banks three ratios were used:

- Loan-to-Deposit_1 (LtD) - ratio of gross loans of the nonfinancial sector to deposits of the nonfinancial sector; 
- Loan-to-Deposit_2 (LtD_2) - ratio of loans of the nonfinancial sector, government and self-government institutions' sector to the total sum of deposits (all groups of entities, i.e. financial, nonfinancial and public sectors);

- Gap - difference between the value of deposits of the nonfinancial sector and loans for the nonfinancial sector.

The first ratio (LtD) does not include the value of deposits and loans of the government and self-government institutions' sector. It refers only to the key data relevant for the nonfinancial sector. The public sector rarely plays a significant role for a loan-deposit activity of the credit cooperative. Additionally the cooperative banks are mostly depositors for communes (Polish: gminy) and districts (Polish: powiaty) rather than lending institutions. However, in case of the second ratio (LtD_2) this limitation was removed. The LtD_2 ratio reflects the loan and deposit data for the public sector as well. Moreover, the value of deposits raised form the financial sector was included. The ratio does not include the financial sector's loans which were treated as secondary investments complimentary to the banks' activities. The ratios reflecting levels of surplus (both LtD and LtD_2) are relative measures that were not standardized. Their values so much different from one will prove imbalance in net transfers. If the LtD ratio (and LtD_2) is in the range of:

- $(0-0,9>-$ then it proves the bank's surplus orientation,

- $(0,9-1,1>-$ then the bank offsets the structure of financing,

- more than 1,1 - then the bank is deficit-like.

In the course of the study the author established a gap reflecting in value terms the scope of imbalance in the researched group of entities.

Next the assessment of conditions for surplus was performed in the researched group of banks. The assessment was performed by means of mathematical models. The LtD ratio was adopted as an endogenous variable of the model. By contrast the exogenous variables were as follows:

- variables describing the scope of the banks' activities, i.e. value of assets (Assets), number of employees (Employment), total sum of deposits (Deposit_sum), value of capitals according to balance sheet (Capitals);

- profitability measured by: net financial result (Result) or returns on assets (ROA);

- safety of activity: capital adequacy ratio (CAR), share of loans with recognized value loss in the loan portfolio of the non -financial sector (Qual_ port); 
- profile of activity; for the research purposes it was essential to identify if the bank's profile of activity is of traditional character, i.e. based on deposit-loan operations. The variables adopted for that purpose are as follows: significance of loans in total assets (Sig_loan), significane of deposits in total assets (Sig_dep), significance of interest results from the bank's activity (Sig_int_res).

The following hypotheses were formulated:

1) The greater the scope of the banks' activities, the lesser the misfit gap in terms of transfers of funds. Larger banks have more possibilities as it comes to granting loans (one should take into consideration limits regarding loan involvement). They also have a larger territory of activity, which may lead to more effective investing in a specific area.

2) There is a negative correlation between the LtD ratio and the safety of a bank's activity. A deficit-like bank (with a low LtD ratio) limits its lending operations by not granting finances to the riskiest prospective clients, which increases its safety.

3) A traditional profile of a bank's activity is related to locality principle. Yet an increase in significance of a bank's deposit activity in the structure of financing a bank leads to a greater misfit of the financing structure. And vice versa, an increase in significance of lending activities in the structure of assets may contribute to surplus limitations.

\section{THE OUTCOME OF THE RESEARCH PROCESS}

In the course of the analysis of data encompassing 1950 observations for each variable, the author established basic descriptive features for the samplings of the groups of banks, both measures of central tendency and dispersion (table 1).

Table 1. Variables describing the researched group of cooperative banks

\begin{tabular}{|l|c|c|c|c|c|c|c|}
\hline \hline \multicolumn{1}{|c|}{ Variable } & $\begin{array}{c}\text { Assets } \\
\text { [thous. } \\
\text { PLN] }\end{array}$ & Employment & $\begin{array}{c}\text { Deposits } \\
\text { [thous. } \\
\text { PLN] }\end{array}$ & $\begin{array}{c}\text { Capitals } \\
\text { [thous. } \\
\text { PLN }\end{array}$ & $\begin{array}{c}\text { Financial } \\
\text { result } \\
\text { [thous. } \\
\text { PLN] }\end{array}$ & $\begin{array}{c}\text { ROA } \\
\text { [\%] }\end{array}$ & $\begin{array}{c}\text { Capital } \\
\text { adequacy } \\
\text { ratio } \\
\text { [\%] }\end{array}$ \\
\hline \hline Mean & 181674.0 & 70.2 & 155483.0 & 18194.5 & 1114.4 & 0.66 & 15.4 \\
\hline Median & 134756.0 & 54.0 & 116793.0 & 13507.6 & 706.3 & 0.56 & 14.2 \\
\hline
\end{tabular}


Table 1. Variables describing the researched group of cooperative banks

\begin{tabular}{|c|c|c|c|c|c|c|c|}
\hline Variable & $\begin{array}{c}\text { Assets } \\
\text { [thous. } \\
\text { PLN] }\end{array}$ & Employment & $\begin{array}{l}\text { Deposits } \\
\text { [thous. } \\
\text { PLN] }\end{array}$ & $\begin{array}{c}\text { Capitals } \\
\text { [thous. } \\
\text { PLN }\end{array}$ & $\begin{array}{c}\text { Financial } \\
\text { result } \\
\text { [thous. } \\
\text { PLN] }\end{array}$ & $\begin{array}{c}\text { ROA } \\
{[\%]}\end{array}$ & $\begin{array}{c}\text { Capital } \\
\text { adequacy } \\
\text { ratio } \\
\text { [\%] }\end{array}$ \\
\hline $\begin{array}{l}\text { Standard } \\
\text { deviation }\end{array}$ & 162323.0 & 49.8 & 140148.0 & 13461.0 & 1241.2 & 0.46 & 4.7 \\
\hline $\begin{array}{l}\text { Coefficient of } \\
\text { variation }\end{array}$ & 0.9 & 0.7 & 0.9 & 0.7 & 1.1 & 0.69 & 0.3 \\
\hline Skewness & 2.4 & 2.2 & 2.4 & 1.9 & 2.8 & 1.31 & 1.6 \\
\hline Kurtosis & 6.5 & 6.2 & 6.3 & 4.5 & 10.3 & 2.26 & 3.8 \\
\hline Percentile 5\% & 47954.0 & 23.0 & 38478.0 & 6305.5 & 150.4 & 0.14 & 10.3 \\
\hline Percentile 95\% & 561195.0 & 169.5 & 489349.0 & 47649.1 & 3670.5 & 1.53 & 24.4 \\
\hline Range Q3-Q1 & 131922.0 & 49.0 & 116117.0 & 13644.4 & 994.7 & 0.60 & 5.1 \\
\hline
\end{tabular}

S o u r c e : own calculations.

By looking at the arithmetic mean and median one can notice that the group of banks in the study is made up of cooperative institutions of average size with assets up to PLN $200 \mathrm{~m}$ and with several dozen employees. However, it is worth noticing that there is a significant variation of the banks under examination. The variation ratios for balance values and financial result values range from $70 \%$ to $110 \%$ (a lower value of the variation ratio applies only to the capital adequacy ratio). Moreover, the skewness ratios indicate a right-tailed asymmetry of distribution, thus significant value dispersion above the mean and concentration of the small ones, the proof of which also lies in the means being higher than the medians.

Table 2. Surplus characteristics in the researched group of cooperative banks

\begin{tabular}{|l|c|c|c|}
\hline \multicolumn{1}{|c|}{ Variable } & LtD & LtD_2 & Gap [thous. PLN] \\
\hline \hline Mean & 0.73 & 0.71 & 36719.1 \\
\hline Median & 0.72 & 0.70 & 27506.0 \\
\hline Standard deviation & 0.23 & 0.20 & 38880.5 \\
\hline Coefficient of variation & 0.31 & 0.28 & 1.06 \\
\hline Skewness & 1.59 & 1.99 & 1.90 \\
\hline Percentile 5\% & 0.43 & 0.47 & -6831.6 \\
\hline
\end{tabular}


Table 2. Surplus characteristics in the researched group of cooperative banks

\begin{tabular}{|l|c|c|c|}
\hline \hline \multicolumn{1}{|c|}{ Variable } & LtD & LtD_2 & Gap [thous. PLN] \\
\hline \hline Percentile 95\% & 1.08 & 1.00 & 104156.0 \\
\hline Range Q3-Q1 & 0.27 & 0.23 & 41485.8 \\
\hline \hline
\end{tabular}

So u r c e : own calculations.

Both of the surplus ratios (LtD and LtD_2), illustrate surplus tendency of the researched banks. Their means are quite approximate and stand at 0.7. A bit lower LtD_2 ratios are justified because of the very construction of the ratio. It is also worth emphasizing that there is much lower variation in the specified categories as compared to the balance characteristics. For the LtD ratio the values on the average deviate from the variable by 0.23 , whereas the variation is average (around 30\%). The skewness of dispersion is also lower, yet it is still there. In terms of the quarters of distribution, only 5\% institutions have a $1.08 \mathrm{LtD}$ ratio or higher. Thus 95\% institutions are surplus-like or offset the structure of raised or invested funds. In terms of mean absolute values of money transfers there is significant dispersion in the researched group of banks. For more than $5 \%$ institutions the gap ratio is negative. It is worth noticing, though, that the positive gap ratio for 0.95 percentile is as high as a dozen times or so. It also proves the advantage of the institution and values with positive features.

An econometric regression model was applied to test the research hypotheses. In the first stage the method of least squares was used for the panel model. Yet after the Breusch-Pagan test was applied it turned out that a more appropriate model to be used was generalized least squares. On the other hand the Hausman test made it possible to find out that the most appropriate model for the research was a fixed effects model (Dańska-Borsiak, 2011, p. 44).

The above-mentioned independent variables were compiled in data tables. The Gretl statistical software package was used to test the models. Not all of the variables were significant, hence eventually the panel model explaining the LtD ratio value emerged as follows (table 3). 
Table 3. Model for variable Y: LtD

\begin{tabular}{|l|c|c|c|c|c|}
\hline \hline Indepenedent variable & Coefficient & Stand. Error & t-Student & Value p & Significance \\
\hline \hline const & 2.4516100 & 0.092907 & 26.3878 & $<0.0001$ & $* * *$ \\
\hline CAR & -0.0032189 & 0.000744 & -4.324 & $<0.0001$ & $* * *$ \\
\hline Sig_loan & 0.5382610 & 0.021188 & 25.4038 & $<0.0001$ & $* * *$ \\
\hline Sig_dep & -2.1100500 & 0.091802 & -22.9847 & $<0.0001$ & $* * *$ \\
\hline Sig_int_res & -0.2572830 & 0.055387 & -4.6452 & $<0.0001$ & $* * *$ \\
\hline Assets & $-1.554 \mathrm{E}-09$ & $3.517 \mathrm{E}-10$ & -4.4169 & $<0.0001$ & $* * *$ \\
\hline Deposit_sum & $1.514 \mathrm{E}-09$ & $4.053 \mathrm{E}-10$ & 3.7356 & 0.0002 & $* * *$ \\
\hline Qual_port & -0.3098580 & 0.097057 & -3.1925 & 0.0014 & $* * *$ \\
\hline Result & $3.981 \mathrm{E}-09$ & $1.858 \mathrm{E}-09$ & 2.1423 & 0.0323 & $* *$ \\
\hline LSDV R ${ }^{2}=0.93$ & & & & & $*$ \\
\hline \hline
\end{tabular}

S o u r c e : own calculations.

In the course of the computation of the model the variables that were statistically insignificant were removed from the set of independent variables. LtD in the model signifies 9 exogenous variables, however it is worth mentioning that the impact of assets, sum of deposits and financial result is marginal due to a low coefficient value. Share of deposits in the bank's total assets is the most significant factor for explaining an LtD ratio level. An increase in this share makes the value of the coefficient go down. On the other hand, an increase in the significance of loans in total assets makes LtD go up, thus banks use the raised funds for lending.

In terms of the research hypotheses.

1) One cannot confirm the hypothesis regarding the relationship between the scope of a bank's activity and the level of financing misfit in the cooperative banks. Although the sum of deposits and the value of assets were included in the model the direction of impact on the ratio value is reverse.

2) The hypothesis about negative correlation of surplus with the safety of a bank's activity was confirmed. The lower the LtD ratio, the higher the safety of a bank's activity (measured by capital adequacy ratio and quality of loan portfolio). 
3) The hypothesis about negative direction of the impact of share of deposits on the surplus ratio and positive impact of the share of loans in total asset was confirmed.

Additionally the following regularity was observed: the higher the significance of the result from interest, the Lower the LtD ratio (higher surplus).

\section{CONCLUSIONS}

The principle of locality within the traditional function of cooperative banks in a specific setting is followed to the extent the bank offsets transfers of funds. Nowadays in Poland there is surplus, which leads to the conclusion that the principle of locality is realized only partially. The scope of the diagnosed misfit of streams of funds measured by the LtD ratio also demonstrates the scope of the utilization of funds beyond local environment, i.e. transferring surplus to other participants of the money market. The research revealed relative stability of the selected group of banks in terms of surplus, gradual deepening of the phenomenon and an increase in the number of banks with a significant misfit of financing structure.

The diagnosed phenomenon should become a point of discussion for the cooperative environment. When it comes to decision-making what may be essential from a point of view of particular entities is the relationship between the structure of financing and the scope of activity. More significant lending activity should contribute to a decrease in non-offsetting of streams of funding. However it may occur at the expense of lower safety of the institution's functioning. From the perspective of the cooperative principle (caring about the local environment) a growth in share of deposits in total liabilities does not lead to the realization of the key objective of the cooperative bank's activity because the raised funds can be transferred to other environments.

\section{REFERENCES}

Alińska, A. (2008). Instytucje mikrofinansowe $w$ lokalnym rozwoju społeczno-gospodarczym. (Micro-financial Institutions in Local Socio-economic Development.). Warszawa: Wydawnictwo SGH, Monografie i Opracowania, nr 558, 248-256.

Becchetti, L., Ciciretti, R. \& Paolantonio, A. (2016). The cooperative bank difference before and after financial crisis. Journal of International Money and Finance, 69, 224-246. http://doi.org/10.1016/j.jimonfin.2016.06.016. 
Boscia, V., \& DiSalvio, R. (2009). The Theory and Experience of Cooperative Banking, 9-39. In V. Boscia, A. Caretta, P. Schwizer (Eds.). Cooperative Banking: Innovations and Developments. London: Palgrave Macmillan. http://dx.doi.org/10.1057/9780230235786.

Czopur, S. (2012), Kapitał finansowy banków spółdzielczych. (Financial Capital of Cooperative Banks.). Warszawa: CeDeWu.

Dańska-Borsiak, B. (2011). Dynamiczne modele panelowe $w$ badaniach ekonomicznych. (Dynamic Panel Models in Economic Research.) Łódź: Wydawnictwo Uniwersytetu Łódzkiego, 39-72.

Fonteyne, W. (2007). Cooperative Banks in Europe - Policy Issues. IMF Working Paper, Nr 157.

Giagnocavo, C., \& Gerez, S. (2012). Cooperative bank strategies for social-economic problem solving: Supporting social enterprise and local development. Annals of Public and Cooperative Economics, no 83:3, 281-315. http://dx.doi.org/10.1111/j.14678292.2012.00464.x.

Golec, M.M. (2010). Społeczne uwarunkowania działalności banków spółdzielczych, 63-79 (Social Determinants of Cooperative Banks' Activity.). In M. Stefański (Ed.). Banki spółdzielcze w Polsce w warunkach kryzysu finansowego i gospodarczego. (Cooperative banks in Poland in the Financial and Economic Crisis Conditions.) Włocławek: Wyższa Szkoła Humanistyczno-Ekonomiczna we Włocławku.

Golec, M.M. (2016). Instytucje i usługi bankowe. (Institutions and Banking Services.) Poznań: Wydawnictwo Wyższej Szkoły Bankowej w Poznaniu, 11-70.

Gostomski, E. (2010). Bankowość międzynarodowa, (International Banking.) Gdańsk, $245-256$.

Groeneveld, H. (2017). Snapshot of European Co-operative Banking 2017. Brussels: EACB, TIAS.

Kata, R. (2011). Endogeniczne i instytucjonalne czynniki kształtujące powiązania finansowe gospodarstw rolnych z bankami (Endogenous and Institutional Factors Determining Financial Relationship between Agricultural Holdings and Banks.). Prace Naukowe Wydziału Ekonomii Uniwersytetu Rzeszowskiego, seria: Monografie i Opracowania, nr 14, Rzeszów, 82-145.

Kozłowski, Ł. (2016). Banki spółdzielcze a deponenci. Empiryczna analiza oddziaływań dyscyplinujących. (Cooperative Banks and Depositors: an Empirical Analysis of Disciplinary Interactions.) Warszawa: Wydawnictwo Poltext, 65-90.

Rzerzycka, A., \& Golanowska-Witkowska, G. (2005). Determinanty rozwoju banków spółdzielczych w Polsce. (Determinants of the Development of Cooperative Banks in Poland.). Pieniq̨dze i Więź, nr 4, 105-112.

Siudek, T. (2011). Bankowość spółdzielcza w Polsce w wybranych krajach Unii Europejskiej - wymiar ekonomiczny, organizacyjny i społeczny. (Cooperative Banks in Poland and selected European Union countries-economic, organizational nad social perspectives.) Warszawa: Wydawnictwo SGGW, 265-288.

Szambelańczyk, J., \& Ławrynowicz, M. (2003). Transfer pieniądza na rynkach lokalnych w strukturze spółdzielczego sektora bankowego w Polsce. (Transfer of Money on local markets in the structure of the cooperative banking sector in Poland.) 389-408. In J. Stacharska-Targosz (Ed.). Bankowość korporacyjna i inwestycyjna. (Cor- 
porate and Investment Banking.) Poznań: Wydawnictwo Wyższej Szkoły Bankowej w Poznaniu.

Szambelańczyk, J. (2006). Banki spółdzielcze $w$ Polsce $w$ procesach zmian systemowych. (Cooperative Banks in Poland in the Processes of Systemic Changes.) Poznań: Wydawnictwo Akademii Ekonomicznej w Poznaniu, 111-129.

Zalcewicz, A. (2010). Bank spółdzielczy. Aspekty prawne tworzenia i funkcjonowania. (Cooperative Bank. Legal Aspects of Creation and Functioning.) Warszawa: Wolters Kluwer, 163-209. 